\title{
The value of the exchange rate and the Dutch disease
}

\section{LUIZ CARLOS BRESSER-PEREIRA*}

This paper revisits the original (2008) paper on the Dutch disease, which defined it by the existence of two exchange rate equilibriums (the current and the industrial exchange rate equilibriums). Its novelty is in claiming that, as we have a value and a market price for each good or service, we also have a value and a market price for foreign money. The value is the cost plus reasonable profit corresponding to the exchange rate that makes competitive the country's competent business enterprises; the nominal exchange rates floats around the value according to the demand and supply of foreign money. This basic distinction of the exchange rate in terms of value and in terms of price allows us to understand that the two equilibriums are defined in value terms, and opens room for a clear distinction of the policies that affect the value from the ones that affect the market price of the exchange rate.

Keywords: Dutch disease; exchange rate; value; market price.

JEL Classification: D46; F31.

The exchange rate is the more strategic macroeconomic price existing in market economies. The other macroeconomic prices - the interest rate, the profit rate, the wage rate and inflation - are also important, but none of these prices have a so powerful effect on the growth and stability of a national economy than the exchange rate. Yet, for long it was relegated to textbooks in international economics; only in the 1980s became essential part of macroeconomics; and up to today is excluded from development economics because its fluctuations would be just a short-term phenomenon. Consequently, it was only viewed as a price determined by the demand and supply, and no discussion was made on the value of the exchange rate, or, in other words, on the value of the foreign money in terms of the

* Emeritus professor of Getulio Vargas Foundation. E-mail: bresserpereira@gmail.com. 
national currency. In this paper I will discuss this question, relating it to the Dutch disease and its neutralization by an export tax, because it was in discussing the Dutch disease that I came to the more general concept of the value of the exchange rate as distinguished from its market price.

\section{DEFINITION}

The Dutch disease is a country's chronic exchange rate overvaluation caused by the exploitation of abundant and cheap resources, whose production and export is compatible with a clearly more appreciated exchange rate than the exchange rate that makes internationally competitive the other business enterprises in the tradable sector that use the most modern technology existing worldwide. It is a structural phenomenon that creates obstacles to industrialization or, if it was neutralized and the country industrialized, but later ceased to be, provokes deindustrialization.

The Dutch disease is a market failure that generates negative externalities in the economy's other sectors of tradable goods and services, preventing those sectors from developing, despite the fact of using the best technology and the best administrative practices. It is a market failure that implies the existence of a difference between the exchange rate that balances intertemporally the country's current account and the exchange rate that enables the existence of efficient economic sectors of tradable goods and services other than the commodities benefiting from Ricardian rents. It is a market failure that not even currency crises are able to correct, because it is compatible with the long-term equilibrium of the country's current account. Only when the Dutch disease is neutralized will the market be able to draw the market exchange rate closer to the competitive equilibrium - the one I call "industrial equilibrium" - , which allocates human resources in a reasonably efficient way in so far as it opens room for productive sophistication or industrialization lato sensu.

Commodities give rise to the Dutch disease or the natural resources curse because they benefit from Ricardian rents: ${ }^{1}$ their market price is defined on the international market by the less efficient marginal producer admitted to the market. The difference between the cost equivalent to this price and the cost of a country in producing the commodity on account of its natural resources is the Ricardian rent. Usually the Dutch disease is associated with a sole good (oil) or with a limited number of goods produced with these natural resources. Whereas, in Ricardo's model, the Ricardian rents benefit only the owners of the most productive lands, in the case of the Dutch disease, if they are not neutralized, they will benefit, in the

\footnotetext{
${ }^{1}$ Note that I don't distinguish the Dutch disease from the natural resources curse. Some authors understand the natural resources curse to the rent-seeking that usually follows the exports of oil and other mineral resources in poor and authoritarian countries. Such rent-seeking is really a problem, but it should not be used to disregard the key economic problem that is the overvaluation of the exchange rate caused by the existence of Ricardian rents.
} 
short run, all the country's consumers, because they buy tradable goods cheaper than those that would prevail should the exchange rate be in equilibrium, but they will hinder the consumers in the medium term, because they compromise impede productive sophistication, i.e., the transfer of labor to industries with higher valueadded per capita - a transfer that is the primary source of increase of productivity in developing countries.

In contrast to what happens with the original Ricardian rents, in the Dutch disease's model there is no difference in productivity between local producers, but just a difference in the country's productivity with regard to the international price (that is, between the average productivity of the local producers and the average of the other countries' producers).

The Dutch disease model that I present in this paper is an improved version of the first one (Bresser-Pereira, 2008), in which the definition of two equilibrium exchange rates in the presence of the Dutch disease - the current equilibrium exchange rate and the industrial equilibrium exchange rate - was already clear, but the existence of a value for the exchange rate associated with a "necessary price" and with a "base price" - both well distinguished from the market price or from the nominal exchange rate - was merely suggested. In this paper I define clearly the value of foreign money, what allows me explain more clearly why the neutralization of the Dutch disease is achieved through the imposition of an export tax on the commodities that give rise to it.

This is the second theoretical model on the Dutch disease. The first one, from Corden and Neary $(1982,1984)$ was a significant contribution, but it is a neoclassical model that does not place at its core the exchange rate, but underlies the existence of two sectors in the economy. In addition, it is a short-term neoclassical model that is concerned with the change caused by the exploitation and export of an abundant and cheap natural resource, and it is only partially a macroeconomic model because it has no money (only relation between currencies) and presumes full employment. The model I present is a Keynesian-structuralist one, which adopts the classical notion of labor-value or, more practically, the concept of value as the cost plus a reasonable or satisfactory profit margin, which corresponds to Marshall's concept of value either in the long run or in secular terms (not in the short run).

\section{ONE MARKET EXCHANGE RATE IN TERMS OF PRICE}

In the presence of the Dutch disease, even those goods produced with the best technology are not economically viable in a competitive market. If a new business enterprise utilizing modern technology is established in a country affected by this disease (all the other competitiveness factors being equal), it will only be economically viable if its productivity is greater than the productivity achieved by business enterprises in rival countries to a higher or equal degree of the appreciation caused by the disease. This fact leads to the conclusion that, in countries suffering from the Dutch disease, besides the nominal exchange rate prevailing at every moment 
on the market, there are two equilibrium exchange rates: the current equilibrium exchange rate - that balances intertemporally the country's current account and, therefore, is also the value around which the market exchange rate will float, or the price to which the market exchange rate should converge; and the industrial equilibrium exchange rate is the value of foreign money that makes competitive the business enterprises producing tradable goods and services using worldwide stateof-the-art technology, is the necessary price around which the market exchange rate should float in a well-behaved market. Thus, when a country has the Dutch disease, it has two exchange rates in terms of value, the current equilibrium exchange rate, $\varepsilon_{\mathrm{c}}$, and the industrial equilibrium, $\varepsilon_{i}$; the market or nominal exchange rate will float around the former - the lower or more appreciated one.

The industrial equilibrium exchange rate is the true equilibrium rate; it is the country's competitive exchange rate, the one that it should pursue in order to develop. The fact of being different from the current equilibrium rate reveals a severe market failure, because it goes against the basic principle of economic theory according to which in a market economy the efficient business enterprises are supposed to be competitive. In a country without the Dutch disease the current equilibrium exchange rate corresponds to the equilibrium of the relative prices or, in other words, it obeys to the fundamental law in economic theory - the tendency to the equalization of profit rates. When we have the Dutch disease, it is not the current equilibrium exchange rate, but rather the industrial equilibrium exchange rate - the one resulting from the neutralization of the Dutch disease.

In the presence of a non-neutralized Dutch disease, we have two conditions, either if the manufacturing industry was not developed in the country, or it was. In the first case, the "potential" business enterprises (that may be organized using worldwide state-of-the-art technology) will have an expectation of negative profits and the investment will not be effectuated; if, previously, the Dutch disease had been neutralized and the industrialization had taken place, but, from a certain moment on, this neutralization was abandoned in the name of economic liberalism, the business enterprises in the tradable sector will see their profit rate diminish or become negative (depending on the severity of the disease), and the country will go into a process of premature deindustrialization. ${ }^{2}$ In both cases, there will be no equality of opportunity between competing business enterprises worldwide, which is the basis for the good operation of the market.

In simple terms, in terms of price, the exchange rate is the price of the foreign currency, it is the nominal exchange rate, $\varepsilon$; it results from the foreign currency supply caused by exports and by capital inflows and from the demand for foreign currency derived from imports, net profit remittances, and capital outflows. It is in

\footnotetext{
${ }^{2}$ In this second case are middle-income countries such as Brazil. Brazil industrialized between 1930 and 1980 through the use of several Dutch disease neutralization mechanisms, usually involving multiple exchange rates. However, as of 1990 it liberalized its trade and financial account, and premature deindustrialization established in the country (Bresser-Pereira, 2010, chap. 6).
} 
equilibrium when the country's current account is balanced intertemporally. Measured in terms of domestic currency, the exchange rate is equal to the price in domestic currency of the representative merchandise, $\mathrm{p}_{\mathrm{x} \# \text {, }}$ divided by its price in foreign currency, $\mathrm{p}_{\mathrm{x} \$}$.

The exchange rate is in equilibrium when the current account is in equilibrium. If it presents a chronic deficit or a chronic surplus, which have to be financed respectively by capital inflows or result in capital outflows, the resulting market exchange rate will be respectively more appreciated or less appreciated than the equilibrium one. Capital inflows and outflows that are not directly related to the current account deficit or surplus are the central obstacle to such correspondence between current account deficits or surpluses have a direct effect on the market exchange rate, but, as I will argue, concerns about the volatility of the exchange rate are often exaggerate.

\section{TWO EQUILIBRIUMS IN TERMS OF VALUE}

But we may also think the exchange rate in terms of value. In much the same way as the value of a merchandise corresponds to the cost plus the satisfactory profit margin of the efficient business enterprises, the value of the exchange rate corresponds to the exchange rate that covers the cost plus a reasonable or satisfactory profit margin of the efficient business enterprises that produce tradable goods. The market or nominal exchange rate floats around this value according to the supply and demand of foreign currency. In the absence of the Dutch disease, the current necessary price and the industrial necessary price are equal, the value of the exchange rate corresponds to the current equilibrium exchange rate, $\varepsilon_{c}$, and the exchange rate market price or nominal price will fluctuate around this value. For sure, we may say that the current equilibrium exchange rate is not a value per se, but a relative price that expresses the value of the goods and services produced by two representative business enterprises, one representing the national business enterprises and the other, the foreign ones. But the values of merchandizes are also expressed in relative prices. Besides, since we are thinking in terms of necessary prices, they are not really prices but values expressed in terms of prices. When we speak of a necessary price, we are referring to value.

In the absence of the Dutch disease, the current and the industrial equilibrium are equal, and the market exchange rate converges to it.

Yet, when the Dutch disease is present, we need to make a distinction between two necessary prices or values: the current necessary price, $\mathrm{p}_{\mathrm{xc}}$, which is the necessary and satisfactory price for the business enterprises that produce and export the commodity(ies) originating the Dutch disease, and the industrial necessary price, $\mathrm{p}_{\mathrm{xift}}$, which applies for the other efficient business enterprises that adopt world stateof-the-art technology in producing tradable goods. The current equilibrium exchange rate corresponds to the current necessary price; it is the value around which the exchange rate market prices floats. It floats around it and not around the in- 
dustrial equilibrium exchange rate, because the current necessary price is the lower price, is the lower cost plus reasonable profit margin, and it is necessarily the lower cost that determine the market price.

Since the market exchange rate will converge the current equilibrium, the other business enterprises in the tradable sector (those not benefiting from Ricardian rents) will become economically non-viable although they use world state-ofthe-art technology, because the industrial necessary price (which they determine) is more depreciated than the current necessary price. Both the current necessary price and the industrial necessary price are really values that represent the average of the cost plus reasonable profit of all goods produced efficiently, while the nominal or market exchange rate is the exchange rate in price terms.

\section{UNIT LABOR COSTS, REAL EXCHANGE RATE, AND PPP}

The value (both the current and the industrial price) depends on the average productivity of the efficient business enterprises that produce tradable goods and services and on the average wages they pay or, in other words, on the unit labor cost (wage divided by productivity). We may, therefore, have an idea about the variations in the industrial equilibrium exchange rate by comparing the country's unit labor cost with the labor unit cost of a currency basket proportional to the country's foreign trade and seeing how it behaves. I always knew the close relation of the unit labor cost with the exchange rate, but it was only when I realized that this was a measure of the relative exchange rates in terms of value, not in terms of price, that all pieces of the puzzle fit together. When we see the exchange rate in value terms, we see it in terms of relations between unit labor costs, i.e., in terms of real wages and increase in productivity. We know that change in labor unit costs in one country in relation to its commercial partners means change in the exchange rate, but this does not happen through the demand and supply of foreign money; this happens due changes in the unit labor costs. If we have good reasons to believe that in a given period the industrial equilibrium exchange rate and the current equilibrium exchange rate were reasonably paired, we will be able to evaluate the evolution of the industrial equilibrium through the evolution of the relative unit labor cost (Marconi, 2012). ${ }^{3}$

Thus, the Balassa-Samuelson mode, which shows the relation between productivity and the exchange rate is also a model thought in terms of value. In that model an exogenous increase in the home country's productivity in the tradable goods sector while the productivity in non-tradable goods sector remains constant will lead to an appreciation of the real exchange rate. Thus, a change in the relative

\footnotetext{
${ }^{3}$ In this paper, the reference period in which the market exchange rate corresponded to the industrial equilibrium was 1975-1980. Departing from this basis, the industrial equilibrium index was calculated in 2010 prices. In this year it was $\mathrm{R} \$ 2.75$ per dollar.
} 
price of tradable relative to non-tradable goods and services, which is independent of the demand and supply of foreign money is determining factor of the exchange rate; not of the market exchange rate, but of the value or necessary price of the exchange rate.

Which is the relation of this value with the concept of real exchange rate instead of nominal exchange? And, also, with the purchasing power parity theory? These two concepts also refer to the value of the exchange rate, not to its market price. The real exchange rate in aggregate and monetary terms is equal to the nominal exchange rate times the domestic aggregate price level divided by the foreign aggregate price level. If we take a period in which we believe that the market exchange rate is in the current equilibrium and create an index of the real exchange rate by deflating it by a price index, we will have the real exchange rate for this chosen period and an index of its variations. While the nominal market exchange rate will vary according to the inflation in the relative currencies, the real one will neutralize such variations, and will vary just in consequence of the supply and demand for foreign money which depend of the current account (of the terms of trade embodied in the current account), and of the capital net flows, independently of these net capital flows being caused by the changes in direct foreign investments, in financial speculation, or in central banks' policy of buying and selling reserves. Thus, the concept of the real exchange rate is not the same thing as the value of the exchange rate, but has a clear relation to it. If we build an index of real exchange rate adopting as basis the same period adopted for an index of the value of the exchange rate (a period in which the market exchange rate corresponded approximately to the industrial equilibrium exchange rate), the two indexes will be equal provided that the relative unit labor costs keep constant during the whole period that the two indexes cover. As to the PPP, the same reasoning applies. If we suppose that the index of the real exchange rate is always 1 , we have the PPP theory. Thus, the real exchange rate as well as the PPP theory are not the same as the theory explaining the value of the exchange rate (of the foreign money), but both are referred to it; in fact, they implicitly assume its existence and relevance.

\section{VOLATILITY}

Exchange rates are today more volatile than they were in the past. Its cause is consensual; they became more volatile because capital flows increased enormously since the 1980s. It is often said that it seems that volatile capital flows make exchange rates more volatile than ever and less linked to the real economy than ever, almost detached from the needs of the real economy. Yet, when consider that the exchange rate or the foreign money has a value around which the market price is supposed to turn, this his view must be relativized. Yes, the fact that capital flows became incredibly high increased the volatility of the exchange rate, but they don't make it a random price because it has a fundamental behind it - its value - that markets cannot and do not ignore. 
If the capital flows are near zero, and if the current account are balanced, and, therefore, the current necessary price and the current equilibrium exchange rate correspond to a market exchange rate that brings to zero the country's current account deficit. But if this is not the case; if the country is trying to grow with foreign savings, and if it has a current account deficit covered by capital inflows, the market exchange rate will be more appreciated (or lower) than the current equilibrium exchange rate, and we will have a current account deficit, because to a certain current account deficit corresponds a more appreciated exchange rate than the one that would prevail if the current account deficit was equal to zero.

Regarding the fluctuation or volatility of the market exchange rate, it will be higher the more volatile and unpredictable the capital flows, which will probably be higher the higher the current account deficit. As we shall see, the way of neutralizing the Dutch disease is by imposing a tax on the commodities, which changes the value or the necessary price of the commodities in national currency (the corresponding price to current exchange rate equilibrium), equalizing it to the necessary price of the other tradable goods and services also in national currency (the corresponding price to the industrial equilibrium).

But this neutralization at value level will be, in turn, offset if the country decides to grow with current account deficit or foreign savings, ignoring that there is high rate of substitution of foreign for domestic savings. ${ }^{4}$ In this case, even if the tax is enough to neutralize the Dutch disease, depending on the size of the capital inflows to finance the current account deficit, they will annul the devaluation caused by the tax; the Dutch disease will be neutralized but the efficient business enterprises in the tradable sector will continue to be economically nonviable.

\section{SEVERITY OF THE DUTCH DISEASE}

We can identify three paradigmatic conditions of the incidence of the Dutch disease: the discovery of natural resources that benefit from Ricardian rents in a poor country, undermining this country's industrialization; the same discovery in a rich country leading to deindustrialization while it is not duly neutralized; and, finally, the radical liberalization of the country's foreign accounts, both trade and financial, which implies to abandon the policies that neutralize the Dutch disease and also lead to premature deindustrialization. The first case is the case of Saudi Arabia, Venezuela, and many other poor countries; the second one is the case of the Netherlands and the United Kingdom; the third one is the case of Brazil, Argentina and Mexico. In the first case, it has always existed and prevented indus-

\footnotetext{
${ }^{4}$ On the rate of substitution of foreign for domestic savings see Bresser-Pereira (2010, chap. 6).
} 
trialization and, therefore, the economic development, as it happened in many oil-producing countries; the second one, more uncommon, took place in the Netherlands, and eventually gave rise the to expression "Dutch disease", because the Dutch understood that they faced an economic disease when they discovered and exploited natural gas in the 1960s. The third one took place mainly in Latin American most developed countries, that had industrialized between 1930 and 1980 adopting several policies to neutralize the Dutch disease (particularly multiple exchange rates, or a system of import tariffs and export of manufactured goods subsidies) although they didn't have this notion perfectly clear. Yet, since the mid 1980s they underwent deindustrialization principally because they radically adopted the trade and financial liberalization proposed by neoliberal ideology, which meant a halt in the neutralization of the Dutch disease and the chronic overvaluation of their currencies. In those countries, where the Dutch disease was not very severe, they eliminated the neutralization mechanisms, the exchange rate appreciated in a durable way, and, as soon as the 1980s financial crisis of the foreign debt was overcome, they once again presented high current account deficits and grew little in the framework of a gradual deindustrialization process. Both in those Latin American countries and in the United Kingdom the Dutch disease caused deindustrialization to be "premature", even if we take into account the increasingly higher labor saving provided by technological progress. As observed by Gabriel Palma (2013, p. 14), in the countries affected by the Dutch disease, which are comprised in cases two and three (United Kingdom and the Netherlands on one hand, Latin American countries on the other), "the fall of the manufactured industry employment was clearly superior to the one that one could expect".

The severity or intensity of the Dutch disease, g, will be higher the higher the difference between the industrial equilibrium exchange rate and the current equilibrium exchange rate, regarding the first one of those rates:

$$
\mathrm{g}=(\varepsilon \mathrm{i}-\varepsilon \mathrm{c}) / \varepsilon \mathrm{i}
$$

Why does the difference between both rates vary and, therefore, the severity of the Dutch disease? This difference will be higher the higher the Ricardian rents involved. Now, the Ricardian rents achieved vary from moment to moment, depending on the international price of the good, and differ from country to country, depending on the cost of exploiting the natural resource (in the oil industry these costs vary enormously). This is the reason why the Dutch disease affects countries in different degrees or intensities depending on these two variables: the international price and the production costs.

\footnotetext{
${ }^{5}$ As remarked by Gabriel Palma (2013: 51-52) in that same paper, in Latin America as of the 1990s, the Dutch disease or syndrome "was basically the outcome of a radical program (extremely strict and without any pragmatism) of trade and financial liberalization, undertaken in the setting of a general process of institutional change".
} 
Example of the severity of the Dutch disease

(where international price, $\mathrm{p}_{\times \Phi^{\prime}}$ is US\$125.00

\begin{tabular}{c|c|c|c|c|c|}
\hline Country & $\begin{array}{c}\text { A } \\
\text { Industrial goods } \\
\text { cost + profit } \\
(\#)\end{array}$ & $\begin{array}{c}\text { B } \\
\text { Commodities } \\
\text { cost + profit } \\
(\#)\end{array}$ & $\begin{array}{c}\text { C } \\
\text { Ricardian Rent } \\
(\#) \\
(A-B)\end{array}$ & $\begin{array}{c}\text { D } \\
\text { Current Equilibrium } \\
\text { (\# per US\$) } \\
(\mathrm{B} / \$ 125.00)\end{array}$ & $\begin{array}{c}\text { E } \\
\text { Severity } \\
\%\end{array}$ \\
\hline A & $\# 200$ & $\# 200.00$ & 0 & 1.60 & 0 \\
\hline B & $\# 200$ & $\# 140.00$ & $\# 60.00$ & 1.12 & $30 \%$ \\
\hline C & $\# 200$ & $\# 40.00$ & $\# 160.00$ & 0.32 & $80 \%$ \\
\hline
\end{tabular}

In order to better understand what I am saying, let's suppose three countries that explore and export oil at a time when the international price of the oil barrel is US\$ 125.00 , the industrial equilibrium necessary price for the business enterprises to produce and export or to face foreign competition is \#200.00 (column A), because they pay the same wages, use the same technology, and portray the same import inputs in relation to costs. But they benefit from different Ricardian rents (due to the cost of drilling oil): in country A, the cost plus the satisfactory profit margin for the commodity-exporting business enterprises is \#200.00, in the country $\mathrm{B}, \# 140.00$, and in the country C, \#40.00; the corresponding Ricardian rents are zero, \#60.00 and \#160.00. Therefore, given that the equilibrium exchange rate is the commodity exporters in the country A will be satisfied with a current equilibrium exchange rate of $\$ 1.60$; the exporters in the country $\mathrm{B}$, with a rate of $\$ 1.12$; and those in the country $\mathrm{C}$, with a current equilibrium rate of $\$ 10.32$, and in these three countries the exchange rates will float around those three values. In country $\mathrm{C}$, the manufacturing industry will be practically nonviable, unless there are very high tariffs or the simple prohibition of importing certain goods. In country B, to run industrial business enterprises will be difficult but not impossible; moderate tariffs may enable the survival of efficient business enterprises, but will not allow the country to export manufactured goods; only incredibly efficient manufacturing business enterprises, or whose imported content is very high will be able to export. Country A will face no problems.

\section{EXTENDED CONCEPT}

The Dutch disease affects not only countries that exploit natural resources. An often-cited origin of long-term appreciation of the exchange rate is the remittances by foreign immigrants. But a significant source of Dutch disease is the combination of cheap labor with a large spread between salaries and wages, what makes it an even more general and more serious market failure. Countries such as China or India will have Dutch disease until wages grow significantly and their 
dispersion diminishes. What explain why these countries manage carefully their exchange rates. They may ignore that the have the Dutch disease - a moderate one - but, as it happened in Brazil between the 1930s and the 1970s (the time of its fast growth) - their policymakers have the intuition of the fact and act correspondingly.

As for the extended Dutch disease, we must take into account the problem of economic growth by transfer of labor from sectors with lower value added to sectors with higher value added. I have said that, in the case of the basic Dutch disease, this wasn't strictly necessary, since the goods giving rise to the disease are not produced with a necessarily lower scientific and technological intensity than the others. I said this considering particularly the oil industry. However, in the case of the extended Dutch disease, this problem exists by definition. Goods produced with cheap labor are basically goods that use low-skilled labor, and, therefore, are products with low technological intensity.

The existence of cheap labor does not generate Ricardian rents but has a similar outcome to the effect of cheap natural resource. The necessary condition for cheap labor is a cause of Dutch disease is that the wage spread is substantially larger than in rich countries - a condition that is usually present because in developing countries the difference between the salaries of engineers and wages of blue-collar workers tends to be much large. The industries using mainly cheap labor have a lower marginal cost than the more technologically sophisticated industries. As a consequence, the exchange rate tends to converge on the level that makes it profitable to export goods that use cheap labor. When this happens - and given the fact that the wages of the more skilled workers and managers are disproportionally higher - , the goods using more sophisticated technology and more expensive labor will be economically compromised. Wages paid in more sophisticated industries shall be necessarily higher, since they use more skilled labor. If the wage difference between an unskilled worker and an engineer, for instance, were approximately 3 to 4 times, as it is in rich countries, the country would produce, with cheap labor, all kinds of goods with no difficulties but the technical and administrative ones. However, if this wage spread is larger, it is 10 to 12 times, whereas in rich countries it is 3 to 4 times, as it usually occurs, then the extended Dutch disease will exist and will become a serious obstacle to economic growth, because industries with higher technological content shall need a higher exchange rate than the current equilibrium exchange rate determined by the market.

Dutch disease's extended concept is not the only one, but is certainly a fundamental reason why dynamic Asian countries manage their exchange rate so hardly, preventing its appreciation. China, for instance, would never be exporting the increasingly sophisticated goods that it exports without managing its exchange rate. By doing that, it keeps the exchange rate at the necessary level - that is, at the industrial equilibrium exchange rate level - that makes economically viable its sophisticated manufacturing industries. 


\section{NEUTRALIZATION}

The neutralization of the Dutch disease always involves the management of the exchange rate or an exchange rate policy, but this is not incompatible with a floating exchange rate. In terms of exchange rate regime, there is nowadays a reasonable consensus in favor of a floating but managed exchange rate in relation to a fix exchange rate. The alternative of the fixed exchange rate was discarded, but this does not mean that the exchange rate should or could be left to the whims of the market. Given the distinction that we made above of value and the market price of the exchange rate, each country is supposed to have a policy for the value and another for the price. In order to neutralize the Dutch disease, the government must act on the value of the exchange rate. It will do that by imposing an export tax on the commodities that originates the disease equal to the difference between the industrial and the current exchange rate equilibrium. This tax will vary from commodity to commodity, and from time to time, depending, respectively, on the Ricardian rents involved, and of the changes in international prices of the commodity. This tax will increase the cost plus reasonable profit of these commodities, thus making current value of the exchange rate equal to the industrial value. Once this shift is implemented, the market exchange rate will float around the same exchange rate equilibrium, around a single value.

Conventional economic policymaking rejects the idea of managing the exchange rate, because they insist on assumption that the market regulates it satisfactorily, and also because they believe that is impossible to change the real exchange rate; that each government can only change the nominal exchange rate. As we just saw, when they are speaking of the real exchange rate, they are, actually, speaking of the value of the exchange rate. Indeed, policies affecting the supply and demand of foreign currency will tend to be ineffective in the long term, but they are effective in the short and medium term in avoiding the overvaluation of the exchange rate caused by excessive or unnecessary capital inflows, which haunt developing countries. And even in the long term, a tax will be able to change the level of the exchange rate, which is determined by its value.

Thus, in devising the exchange rate policy, we should make a distinction between the policies that are applied on the market exchange rate and the policy that should be applied to the value of the exchange rate. The policies to manage the market exchange rate around the equilibrium are well-known; the central bank should keep the domestic interest rate at a low level in order not to attract excessive capitals, and should purchase foreign currency to increase international reserves; the government should adopt capital controls to avoid excessive capital inflows. ${ }^{6}$ These latter are particularly necessary during the periods when foreign investors in financial markets chose the country to make their investments, and also when

\footnotetext{
${ }^{6}$ If the government keeps its foreign accounts balanced, rejecting excessive capital inflows, it will not have to worry about controlling capital outflows.
} 
multinational corporations prove to be particularly willing to invest in the country. Of those three mechanisms, the first two are adopted by practically all the countries, although they do not admit to be managing their exchange rates. The third one is a measure to be adopted only in situations of excessive pressure of the capital flows in appreciating the national currency.

The way par excellence of neutralizing the Dutch disease by operating on the current equilibrium exchange rate is the export tax. ${ }^{7}$ This tax should correspond to the difference between the current equilibrium exchange rate and the industrial equilibrium exchange rate, or between the current necessary price and the industrial necessary price, so that the supply curve of the product in relation to the exchange rate (not in relation to the price, which here we presume as given) shifts upwards and to the left up to the level of the industrial equilibrium rate. The Dutch disease will then be neutralized, and the country will present a current account surplus, provided that the currency supply and demand is balanced. The surplus will be greater the more serious the Dutch disease.

Many economists - and in this case not only conventional ones but also structuralist and Keynesian economists as well - have difficulty understanding why a tax will devaluate permanently the exchange rate, because they often think of it as being determined only by the currency supply and demand. From this assumption, which does not distinguish the market price of the exchange rate from the necessary price or the value of the exchange rate, it is, indeed, impossible to understand why a tax, which has no direct effect on the currency supply and demand of foreign money, neutralizes the Dutch disease. Also for failing to see that actually the exchange rate is determined both by its value, in the long term, and by the variations of supply and demand, in the short run, they think that the export tax would have this effect if the money collected by the state through the tax would be invested outside the country, which would not entail, therefore, an increase in the supply of foreign currency in the domestic market.

In any case, in so far as the country that is successful in neutralizing the Dutch disease with the imposition of a tax on the commodities that originate it moves from the current to the industrial equilibrium, it will necessarily present a current account surplus. Yet, despite setting a export tax at the adequate level, the country may, nevertheless, present an zero or negative current account if it decides for a rather strange (but common in Latin American countries) policy: of neutralizing the neutralization of the Dutch disease by either trying to control inflation with the exchange rate, or by trying to grow with foreign savings, i.e., with current account deficits, or, finally, by practicing "exchange rate populism", i.e., to appreciate the currency to rise artificially wages and consumption. This was the case of Argentina since the late 2000:

\footnotetext{
${ }^{7}$ The tax should not, in principle, be imposed only on exports, as it happens in Argentina since 2002, when the Dutch disease was neutralized by the "retenciones", because this implies an artificial deviation of the production towards the domestic market. Argentina's depreciation came from the crisis, not the tax. The tax helped to reduce the extreme profits = rents of commodity producers.
} 
it neutralized the Dutch disease by an export tax, but let it appreciate in the following years to control inflation and assure reelection of the president. But this situation is still more favorable than of most Latin American countries that besides not neutralizing the Dutch disease, appreciate additionally their currencies by a combining the use of the exchange rate as an anchor against inflation with exchange rate populism and the policy of growing with foreign savings.

When we think about the exchange rate in the long run in terms of value, we understand why the tax neutralizes the Dutch disease by shifting the current equilibrium exchange rate towards the industrial equilibrium. The tax in domestic currency should be equal to the difference between these two rates. When the State imposes the tax, the cost plus the reasonable profit margin for the commodity exported - its value, therefore - shifts upwards in the same measure, the current necessary price and the industrial necessary price equalize, and the Dutch disease is basically neutralized, without the need to interfere with the supply and demand of foreign currency. The shift took place in the value and the price now floats around the new value.

This kind of neutralization is completed by the creation of an international fund with the revenues derived from this tax; the fund will prevent the inflow of tax revenues from partly leading to the reappreciation of the exchange rate through the supply effect; or, in other words, it will make it easier for the government to adopt a policy of equating the country's net capital outflows with its current account surplus. This was essentially what Norway did after it discovered and started to export oil in the North Sea. Great Britain, that discovered oil at the same time, did not neutralize the Dutch disease and its economy suffered the consequences (Chatterji and Price, 1988). Chile also neutralizes adequately the Dutch disease by heavily taxing copper exports and having created a copper fund, but it is a partial neutralization probably because the tax is insufficient. All the oil-producing countries tax their exports, but usually at a level that is unable to neutralize the Dutch disease. Norio Usui (1998) studied the cases of Indonesia and Mexico and showed that, while Indonesia neutralized adequately the Dutch disease, Mexico did not. According to him, Indonesia's greater fiscal discipline enabled this country to buy and sterilize reserves, in order to avoid exchange rate appreciation, by paying a very low interest rate on these acquisitions. But Indonesia's case was not an example of neutralization of the Dutch disease; it was rather a case of limiting the supply of foreign money through monetary policy. Nevertheless, according to Jan Priewe's (2012) calculations, the windfalls were too strong to fully avoid appreciation; later, he, complements, the appreciation was corrected with the "help" of the 1996 Asian crisis...

\section{WHO PAYS FOR THE NEUTRALIZATION?}

Once established an export tax, we just saw that the supply curve of the commodity will shift upwards and to the left with regard to the exchange rate, that is, the producers will only be inclined to maintain production if the exchange rate 
depreciates in an amount corresponding to the tax. Therefore, if the tax is equal to the difference between the current equilibrium exchange rate and the industrial equilibrium exchange rate, the first one will shift towards the second one and the Dutch disease will be neutralized. Thus, an interesting thing is that the commodity exporters that formally pay the tax eventually will not pay it, because, as a trade off, the exchange rate will devalue in the same amount of the tax, assumed a reasonably free market. Who will pay? The country's population as a whole will pay it through the relative increase in the price of tradable goods resulting from the depreciation.

Figure 1: Neutralization of the Dutch disease by means of a tax on exports

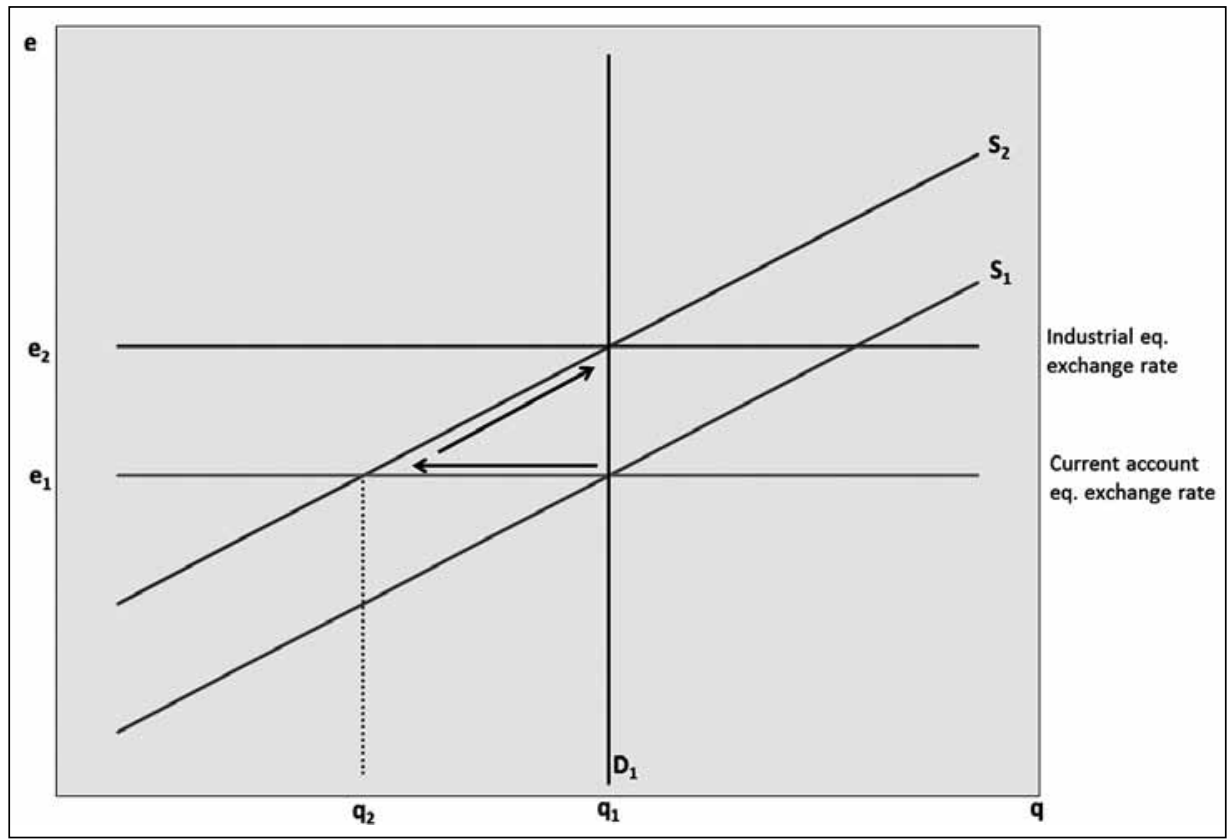

The neutralization of the Dutch disease with the help of an export tax can be easily understood with the Figure 1 . We have the exchange rate (not the price) in the vertical line, and the quantities in the horizontal line. The difference between $\mathrm{e}_{1}$ (the current equilibrium exchange rate) and $\mathrm{e}_{2}$ (the industrial equilibrium exchange rate) is the size of the Dutch disease in the domestic currency. $\mathrm{D}_{1}$ is the international demand curve for the commodity in relation to the exchange rate; it is fully inelastic since the exchange rate of the country does not affect it. The world demand and the international prices are given; if the country is big enough to affect the total supply of the commodity, that would complicate the figure, because it would be necessary to consider first the shift of the demand curve backwards and a little later forward, but it would not change the analysis. Given the demand and the exchange rate, the quantity exported is $\mathrm{q}_{1}$.

The supply curves, $S_{1}$ and $S_{2}$, are respectively the supply of the commodity 
before and after the export tax, which is equal to the size of the Dutch disease $\left(e_{1}-e_{2}\right)$. These are supply curves defined in terms of the required price to make business enterprises cover their cost plus reasonable profit margin. As elementary microeconomics teaches, the tax causes the shift of the supply curve. The quantity offered at this exchange rate falls to $\mathrm{q}_{2}$, because the less efficient producers will consider stopping production. But since the demand is inelastic in relation to the exchange rate, and, thus, constant, the exchange rate will depreciate from $\mathrm{e}_{1}$ to $\mathrm{e}_{2}$, so as to reestablish the equilibrium between the existing supply and demand.

Let's assume, for instance, that the industrial equilibrium is $\mathrm{R} \$ 2.70$ per dollar and the current equilibrium, $R \$ 2.20$ per dollar. If the effective exchange rate is in current equilibrium, because it is not being appreciated further by excessive capital inflows, a tax of $\mathrm{R} \$ 0.50$ per dollar will move the exchange rate to $\mathrm{R} \$ 2.70$ per dollar. The tax should be variable to be changed by the government as the international price of the commodity changes substantially.

Thus, what the producer pays in tax he receives back in depreciation. If we suppose that both changes are immediate, he will bear no cost. If we abandon such assumption - which is more realistic — there will be a "transition cost" for him, which explains why commodity exporters are so keen in opposing the tax. Labor will have to pay a similar transition cost, because their real wages will fall for a while. The difference is that workers will soon be compensated by a substantial increase in rate of increase of the wage rate that will follow, while the commodity exporters will be just back to their original position. This suggests that the government will have more difficulty with them, and will probably offer some guarantees as, for instance, that (1) it will make an special effort in terms of increasing capital controls or buying more dollars to make the transition to the new equilibrium faster, and (2) that it will use part of the tax as a guarantee fund for the price of the commodity - which will be attractive if the overappreciation is not to big (or the Dutch disease is not too severe), because, in this circumstance, the price of the commodity may fall enough to make the average producer unprofitable. In this case, besides the tax going to zero, the producer would receive compensation from the fund.

Finally we must know what the government will do with the amount of tax collected. Ideally, it may create international investment funds, as Norway did. ${ }^{8}$ In this case the neutralization is perfect, because there is no foreign currency inflow into the country. As an alternative, the government may spend the revenues from the tax in necessary public investments and in the increase in social expenditure, as Argentina or Chile do; or use the revenues from the tax to reduce or keep low other taxes, as it happens in Mexico; it may be used to establish a stabilization fund that guarantees agricultural producers against violent fluctuations of the international price of the commodities; and, finally, it may let the revenues from the taxes

\footnotetext{
${ }^{8}$ What does not mean that Norway was able to fully neutralize the Dutch disease. To achieve this, its tax on oil should be bigger, what would represent a diminution of wages and consumption in the short run.
} 
be captured by a small group of corrupt politicians, bureaucrats and local capitalists, usually associated with rich countries' business enterprises, as it usually happens in poor oil-exporting countries. In any of those five cases related to the second alternative, the expenditure of the funds from the tax will lead to an increase in the demand for imports, and the exchange rate, that had been depreciated thanks to the tax, will partially appreciate again, while the current account surplus caused by this tax will decrease. Imports seem at first glance a very good tool to dampen DD. Unfortunately, they crowd out domestic industrial production!

Thus, the Dutch disease is not easy to neutralize, because it is not easy to devalue a national currency, and because it is still more difficult do depreciate it and keep it in the new level permanently. The forces that act for the existence of the tendency to the cyclical and chronic overvaluation of the exchange rate, the preference for the short in relation to the long term, the fear of short-term losses that are necessarily large in major devaluations are all strong. To move the exchange rate to the industrial equilibrium level and to maintain it at this level depends usually of a strong developmental class coalition.

\section{REFERENCES}

Bresser-Pereira, Luiz Carlos (2008) "Dutch disease and its neutralization: a Ricardian approach", Brazilian Journal of Political Economy 28 (1): 47-71.

Bresser-Pereira, Luiz Carlos (2010) Globalization and Competition. Cambridge: Cambridge University Press.

Chatterji, Monojit and Simon Price (2008) "Unions, Dutch disease and unemployment". Oxford Economic Papers, 40 (2): 302-321.

Corden, W. M. and J. P. Neary (1982) "Booming sector and de-industrialization in a small open economy”, Economic Journal, 92 (368): 825-848.

Corden, W. M. and J. P. Neary (1984) "Booming sector and Dutch disease economics: survey and consolidation”, Oxford Economic Papers, 36 (3): 359-380.

Marconi, Nelson (2012) “The industrial equilibrium exchange rate in Brazil: an estimation", Brazilian Journal of Political Economy, 32 (4): 656-669.

Palma, José Gabriel (2013) “Desindustrialización, desindustrialización 'prematura' y un Nuevo concepto del 'síndrome holandés'”, Cambridge: School of Economics of the University of Cambridge, copy, February 2012.

Priewe, Jan (2012) "Contemporary issues in international economics, trade and finance: Module II Dutch disease, resource curse and development”, UNCTAD, United Nations, New York and Geneva: 2012 (http://vi.unctad.org).

Usui, Norio (1998) "Dutch disease and policy adjustments to the oil boom: a comparative study of Indonesia and Mexico". Resources Policy, 23 (4): 151-162. 